EPiC Series in Language and Linguistics
Volume 1, 2016, Pages 372-380
CILC2016. 8th International
Conference on Corpus Linguistics

\title{
The emerging parties' manifestos for the 2015 Spanish general elections: a comparative analysis of lexical choices
}

\author{
Hanna Skorczynska \\ Universitat Politècnica de València, València, Spain. \\ hskorczy@idm.upv.es
}

\begin{abstract}
The study looks into the lexical choices made in the political manifestos of two new political parties participating in the 2015 Spanish general election: Ciudadanos and Podemos, which share similar programmatic goals and aim to reach voters dissatisfied with the dominating two big parties: the conservative PP and the socialist PSOE. The two manifestos are compared using the 'compare corpora' tool of Sketch Engine, and the keywords and their collocational patterns are analyzed with a special focus on evaluative adjectives. Finally, the two manifestos are also compared to the Spanish presidents' inaugural speeches. The results suggest that the manifestos rely on distinct lexical choices, pointing to differences in the ideological stance. The manifesto of Podemos clearly breaks away from the traditional political discourse in Spain, while Ciudadanos is more conventional in this sense.
\end{abstract}

\section{Introduction}

This study looks into the lexical choices in the political manifestos of two new political parties participating in the 2015 general elections in Spain: Ciudadanos (C) and Podemos (P). In this way, the quantitative data obtained have served to unveil how the new parties' political message varies when the broad programmatic goals, such as democratic regeneration, fight against unemployment and corruption or education reform, are similar. In fact, the leaders of both parties, Albert Rivera (C) and Pablo Iglesias (P) referred to their political manifestos as framed within the social democratic ideology, even though their economic programs differ regarding the degree of the state's interventionism. Albert Rivera, described the ideological stance of his party in the following way: "The program of Ciudadanos is of the Scandinavian social democracy, obviously because it is the most popular model in our country. Garicano himself has said that Denmark is his mirror, that is, a

\footnotetext{
${ }^{*}$ Luis Garicano is the coordinator of the economic program of Ciudadanos.
} 
strong State with high taxes, but with flexible and competitive markets" (El Mundo, 18/02/2015). Pablo Iglesias, in turn, said: "Our proposals are those that have always been made by social democrats" (El País, 27/09/2014), and added: "They [PSOE] have abandoned the social democratic space. We feel comfortable in that space in order to defend social majorities against a privileged minority" (Las mañanas de Cuatro, 18/05/2015).

The two parties, therefore, positioned themselves as an alternative for the two traditionally dominating parties: the conservative Partido Popular and the socialist party PSOE, claiming that they would provide a unique opportunity for regeneration on all levels. They also intended to reach voters from the center of the Spanish political spectrum, even though Ciudadanos advocated economic liberalism, while Podemos, strongly defended economic interventionism. Given this political scenario in Spain in 2015, and the converging political messages coming from the two new parties, I intended in this study to find out how they are articulated on the lexical level, and in particular, how apparently similar political aims are expressed through possibly different lexical choices.

\section{Theoretical considerations}

This study adopts the Critical Discourse Analysis (CDA) perspective, which considers "language as discourse and as social practice" (Fairclough, 2011: 21). and studies the relationship between language and ideology (e.g., van Dijk, 1997; Fairclough, 2001; Wodak, 2001). This study can also be placed within research combining CDA and Corpus Linguistics (CL), as advocated by Stubbs (1997) who suggested using random sampling, analyzing a large collection of text, and comparing the selected textual features with language norms as reflected by a corpus in order to make reliable generalizations about typical language use (Cheng, 2013). Introducing the quantitative methodology of CL, serving to study the lexicogrammatical and collocational patterns of lexical items (Sinclair, 1996) reinforces the CDA approaches that rely more on qualitative descriptions of grammatical or lexical choices made to express social processes and phenomena.

Even though there exists a substantial body of research relying on combined CDA and CL analyses of political discourse, most of those studies focused on newspaper reports, and notably fewer examined political discourse understood as oral and written texts produced and/or delivered by politicians. In this line, Fairclough (2000) analyzed the rhetoric of New Labour by looking into frequency lists and keywords in a corpus of New Labour texts. Cheng (2004) examined the public speeches by the first chief executive of the Hong Kong SAR at two levels of meaning making: collocational and ideational, and Miliza (2006) compared the collocates of 'terror' and 'terrorism' in the US, British and Italian spoken corpora of political discourse.

In this study, the focus will be placed on the lexical choices made in the political manifestos of two parties: Ciudadanos and Podemos, by means of the analysis of the keywords and their collocational patterns, with special attention paid to evaluative key adjectives. This type of analysis relies on the collocational principle or idiom principle proposed by Sinclair (1987: 320), which regards language as composed of preconstructed or semi-preconstructed phrases that constitute single choices. This view can be complemented by Hoey's (2005) lexical priming theory, which considers each lexical item as primed for collocational use.

\section{Corpora and method of analysis}

Two corpora corresponding to two political manifestos have been used for the study: Ciudadanos - nuestras ideas (https://www.ciudadanos-cs.org/) corresponding to C corpus and Programa marco 
(http://podemos.info/), to $\mathrm{P}$ corpus. Both corpora included a similar number of words: 17,473 in $\mathrm{C}$ corpus and 17,537 in P corpus.

According to Charteris-Black (2004), a political manifesto is a document stating the intentions and policies of a political party aiming to persuade the electorate to vote for that particular party. It is normally generated through collaborative processes of drafting and redrafting and entails a multiple authorship. Political manifestos often provide phrases that can be later used in slogans and speeches. Their overall communicative purpose of persuasion focuses not only on the ideology of a political party, but also on the integrity and values of politicians.

In order to provide quantitative data related to the lexical choices made in both corpora, the 'compare corpora' tool of Sketch Engine (https://www.Sketch Engine.co.uk/) has been used. The tool calculates the comparability score for the corpora that one wishes to compare in terms of the lexis used, and in addition, identifies the keywords in one corpus using the other as the reference corpus. In this way, the corpora are rigorously compared to each other. After obtaining the comparability score for $\mathrm{C}$ and $\mathrm{P}$ corpora, the keywords found have been analyzed and their collocational patterns have been identified. The same has been done for the evaluative key adjectives. Finally, $\mathrm{C}$ and $\mathrm{P}$ corpora have been compared to the corpus of the Spanish presidents' inaugural speeches (http://www.lamoncloa.gob.es/presidente/presidentes/Paginas/index.aspx), accounting for 102,433 words. The comparability scores have been calculated for the three corpora, and after that, for each Spanish president. Obviously, presidential inaugural speeches are a distinct type of political discourse from the manifesto of a political party. However, the main communicative aim of persuading the audience of the adequacy of a particular political program is common for these two types of political discourse and has been found to be a sufficient reason to make a comparison. The data obtained have enabled the final estimation of how 'new' the new parties are in the lexical articulation of their political manifesto with reference to the past conservative and socialist presidents.

\section{Results and discussion}

This section will first discuss the comparability scores for $\mathrm{C}$ and $\mathrm{P}$ corpora, after which the keywords in both corpora will be presented, and the use of the evaluative key adjectives will be discussed. Finally, the comparability scores with the corpus of the Spanish presidents' inaugural speeches will be reported in detail.

\subsection{Comparability score for $\mathrm{C}$ and $\mathrm{P}$ corpora}

The comparability score for $\mathrm{C}$ and $\mathrm{P}$ corpora, calculated by Sketch Engine reaches 4.16 points. If the corpora were identical, the comparability score would be 1 point. Therefore, the bigger the score, the greater the lexical differences between two corpora are. The score obtained is relatively high: other scores obtained in the comparison of well-known corpora included on the Sketch Engine website provide a useful reference. For instance, the comparability score for London English corpus (informal conversations in two working-class areas of London) and BAWE corpus (British Academic Written English corpus) reaches 5.84 points, just around 1.5 points above the $\mathrm{C}$ and $\mathrm{P}$ corpora score. It can be claimed, therefore, that $\mathrm{C}$ and $\mathrm{P}$ corpora are quite different with regard to the lexis used, despite the fact that in general terms, their political message seems to be similar. 


\subsection{Keywords in $\mathrm{C}$ and $\mathrm{P}$ corpora}

Keyword analysis focuses on the differences between two corpora, by identifying those words, which are unusually frequent in comparison to a reference corpus. Table 1 shows the list of the top 35 keywords in $\mathrm{C}$ corpus as compared to $\mathrm{P}$ corpus with the corresponding keyness score.

\begin{tabular}{|l|l|l|l|}
\hline Keyword & Score & Keyword & Score \\
\hline C's & 27.4 & inmigrantes & 5.9 \\
partidos & 17.1 & sólo & 5.7 \\
pensiones & 12.4 & nacional & 5.7 \\
CCAA & 9.8 & identidades & 5.7 \\
lengua & 9.3 & democrática & 5.7 \\
ciudadanos & 9.2 & UE & 5.7 \\
estado & 7.9 & necesario & 5.4 \\
empresarial & 7.7 & valores & 5.1 \\
libertad & 7.3 & utilización & 5.1 \\
nuestra & 7.2 & partido & 5.1 \\
imprescindible & 7.2 & inmigración & 5.1 \\
Administraciónes & 7.2 & individuales & 5.1 \\
países & 6.9 & fronteras & 5.1 \\
unos & 6.7 & IVA & 5.1 \\
Europea & 6.6 & Europa & 5.1 \\
España & 6.4 & cultura & 4.9 \\
mercado & 6.2 & español & 4.8 \\
lenguas & 5.9 & & \\
\hline
\end{tabular}

Table 1: Keywords in $\mathrm{C}$ corpus as compared to $\mathrm{P}$ corpus

As can be seen in Table 1, the top 35 keywords belong to six broad semantic fields: those referring directly to Spain (España, español, nacional), to the state organization (CCAA, Administraciones, estado, paises, fronteras, democrática, ciudadanos, partidos, libertad), the European Union (Europea, $U E$ ), culture (lengua, lenguas, cultura), market economy (empresarial, mercado, IVA), immigration (inmigrantes, inmigración), and need (imprescindible, necesario).

Table 2 includes the top 35 keywords in $\mathrm{P}$ corpus in comparison to $\mathrm{C}$ corpus.

\begin{tabular}{|l|l|l|l|}
\hline Keywords & Score & Keyword & Score \\
\hline Se & 10.1 & autónomas & 5.1 \\
autónoma & 8.4 & puesta & 5.0 \\
género & 7.9 & energético & 5.0 \\
plan & 7.0 & Rescate & 5.0 \\
civil & 7.0 & menores & 4.9 \\
gente & 6.5 & importan & 4.5 \\
Pública & 6.5 & escolar & 4.5 \\
violencia & 6.0 & deporte & 4.5 \\
recuperación & 6.0 & contaminantes & 4.5 \\
etcétera & 6.0 & bonificaciones & 4.5 \\
ejercicio & 6.0 & Pondremos & 4.5 \\
deuda & 5.6 & Elaboraremos & 4.5 \\
vacías & 5.5 & Desarrollaremos & 4.5 \\
\hline
\end{tabular}




\begin{tabular}{|l|l|l|l|}
\hline pago & 5.5 & diseño & 4.3 \\
ambiental & 5.5 & Garantizaremos & 4.3 \\
red & 5.2 & nuevo & 4.1 \\
pobreza & 5.2 & rural & 4.0 \\
marcha & 5.2 & & \\
\hline
\end{tabular}

Table 2: Keywords in $\mathrm{P}$ corpus as compared with $\mathrm{C}$ corpus

On the whole, the keyness scores in P corpus are slightly lower for the top 35 keywords than in $\mathrm{C}$ corpus, which indicates that the keywords in the latter registered higher ranges of unusual frequency. In other words, and in very broad terms, $\mathrm{C}$ corpus seems to show more lexical differences than $\mathrm{P}$ corpus does so in comparison to $\mathrm{C}$ corpus.

The broad semantic fields into which the keywords from Table 2 can be grouped are: current problems in Spain (pobreza, contaminantes, violencia, género, deuda, vacías, pago), solutions to current problems in Spain (plan, recuperación, marcha, puesta, rescate, bonificaciones, pondremos, elaboraremos, desarrollaremos, garantizaremos, nuevo, diseño, ejercicio), child education (menores, escolar), sports (deporte), and rural areas (rural).

What draws attention are, on the one hand, the keywords with the negative meaning referring to problems, and, on the other hand, the keywords with the positive meaning referring to solutions. In addition, the positive meaning keywords clearly outnumber the negative ones, suggesting that the message in $\mathrm{P}$ corpus is articulated mostly in positive terms, even though it arises from an opposition between the negative and the positive. This dualism possibly strengthens the communicative and so, the persuasive aspect of the manifesto in a straightforward and direct manner.

\subsection{Closed-class keywords and their collocational patterns}

In order to analyze the collocational patterns of the closed-class keywords in $\mathrm{C}$ and $\mathrm{P}$ corpora, the first five keywords have been selected from each corpus. Table 3 shows the words that have been used in combination with the first five keywords in $\mathrm{C}$ corpus.

\begin{tabular}{|l|l|}
\hline Keyword & Collocates \\
\hline C's & $\begin{array}{l}\text { defiende, necesario, principios, pensamos, importante, } \\
\text { integración }\end{array}$ \\
\hline partidos & $\begin{array}{l}\text { políticos, donaciones, nacionalistas, responsabilidad, } \\
\text { financiación }\end{array}$ \\
\hline pensiones & sistema, público, reforma \\
\hline CCAA & común, Estado \\
\hline lengua & oficial, España \\
\hline
\end{tabular}

Table 3: The first five keywords and their collocates in $\mathrm{C}$ corpus

As can be seen in Table 3, the top keyword C's (Ciudadanos) has been used in combination with the words that seem to be typical for any political manifesto: 'defends', 'principles', or 'we think'. Moreover, 'parties', used with 'political', 'responsibility', 'donations,' or 'financing' indicate how concerned Ciudadanos is with the role that political parties should play with regard to the state, the society and the social issues. Table 3 also includes the words that are indicative of the most important concerns of the party such as the pension system reform, the strength of the autonomous region system and the use of the official languages in Spain.

Table 4 shows the first five keywords in P corpus and their collocates. 


\begin{tabular}{|l|l|}
\hline Keyword & Collocates \\
\hline autónoma & comunidad, voluntad, manera \\
\hline género & violencia, desigualdad, igualdad, discriminación \\
\hline plan & $\begin{array}{l}\text { rescate, contra, garantía, pagos, microcréditos, recuperación, } \\
\text { energético, autonómico }\end{array}$ \\
\hline civil & sociedad \\
\hline gente & para, somos, sufre \\
\hline
\end{tabular}

Table 4: The first five keywords and their collocates in P corpus

As Table 4 shows, there is only one similar keyword to those included in Table 3: 'autonomous', making reference to autonomous regions (comunidad), but also combining with other general meaning words such as 'willingness' and 'manner'. The remaining keywords place an emphasis on different matters from $\mathrm{C}$ corpus: gender violence and discrimination, action plans (plan de rescate, plan contra, plan de pagos, plan de microcréditos, plan de recuperación, etc.), the civil society and people. It is very significant that the word 'people' is a keyword in P corpus: it has been used in combinations such as 'for the people', 'we are the people' or 'the people suffer'. Here again the political message revolves around people's problems and solutions to those problems rather than the issues reflecting the functioning of a democratic state.

\subsection{Evaluative key adjectives in $\mathrm{C}$ and $\mathrm{P}$ corpora}

As Table 5 below shows, two evaluative key adjectives have been identified in each corpus.

\begin{tabular}{|l|l|l|l|}
\hline C corpus & Score & P corpus & Score \\
\hline imprescindible & 7.2 & vacías & 5.5 \\
necesario & 5.4 & nuevo & 4.3 \\
\hline
\end{tabular}

Table 5: Evaluative key adjectives in $\mathrm{C}$ and $\mathrm{P}$ corpora

Evaluative adjectives play an important role in building a persuasive political message. The key adjectives with the evaluative meaning in $\mathrm{C}$ corpus denote necessity and importance, while in $\mathrm{P}$ corpus, they reflect the opposition between the positive ('new') and the negative ('empty'). The collocational patterns in which these adjectives have been used provide more information about the differences between the two political manifestos under study (Table 6).

\begin{tabular}{|l|l|c|l|}
\hline \multicolumn{2}{|c|}{ C corpus } & \multicolumn{2}{c|}{ P corpus } \\
\hline imprescindible & $\begin{array}{l}\text { separar, coordinar, fabricar, } \\
\text { elaborar, establecer, armonizar, } \\
\text { aumentar, mejorar }\end{array}$ & nuevo & $\begin{array}{l}\text { modelo, programa, marco, } \\
\text { objetivo, parlamento, patrón, } \\
\text { personal, proceso }\end{array}$ \\
\hline necesario & $\begin{array}{l}\text { diseñar, acercar, adoptar, } \\
\text { avanzar, establecer, incrementar, } \\
\text { plantear, dar, modificar, rebajar }\end{array}$ & vacías & viviendas, promesas \\
\hline
\end{tabular}

Table 6: Collocational patterns of the evaluative key adjectives in $\mathrm{C}$ and $\mathrm{P}$ corpora

Apart from being used in distinct syntactic structures (copular structure in $\mathrm{C}$ corpus and noun phrases in $\mathrm{P}$ corpus), the focus in $\mathrm{C}$ corpus is placed on the need to undertake all types of action, which is expressed through the verbs such as 'separate', 'coordinate', 'elaborate', 'improve', 'design', 'adopt', 'advance', 'increase', 'modify' or 'reduce'. On the contrary, 'new' in P corpus combines with 
more general meaning and abstract nouns, for instance 'model', 'program', 'framework', 'process' or 'pattern', while 'empty' is used in the context of the housing problem in Spain consisting in the excessive number of empty flats and houses owned by banks. 'Empty' has also been used in 'empty promises' with reference to disappointment with the previous governments. The examples below provide more context for the use of the collocations from Table 6.

(1) Hemos de aumentar la productividad de nuestras empresas, y para ello es imprescindible fabricar bienes y elaborar servicios de más valor añadido (...). (C corpus)

We need to increase the productivity of our companies, and to this end, manufacturing goods and creating services with more added value is essential (...).

(2) Asimismo es necesario diseñar una nueva política industrial para los próximos años cuyas claves deben ser: (...). (C corpus)

In addition, it is necessary to design a new industrial policy for the next years, the key elements of which should be: (...).

(3) En esta línea, es necesario traspasar de manera efectiva las oficinas de servicios sociales básicos a los municipios. (C corpus)

In this line, it is necessary to effectively move the basic service offices to the municipalities.

(4) Nuevo modelo productivo de planes autonómicos de mejora de la competitividad. (P corpus)

New productive model for the autonomous plans to improve competitiveness.

(5) Un segundo objetivo de estas medidas debe ser crear un nuevo patrón energético que reduzca el peso de aquellos sectores insostenibles y con mayor carga de emisiones en CO2. (P corpus)

A second objective of those measures should be the creation of a new energetic model which would reduce the weight of those unsustainable sectors with the highest $\mathrm{CO} 2$ emissions.

(6) Apertura de expediente sancionador para aquellas empresas o particulares con más de diez viviendas vacias. ( $\mathrm{P}$ corpus)

The opening of disciplinary proceedings for those companies or individuals with more than ten empty flats or houses.

\subsection{Comparability scores with the Spanish presidents' inaugural speeches}

In order to find out how 'new' political manifestos of the new political parties participating in the 2015 Spanish general election are in terms of the lexical choices made, the Spanish presidents' inaugural speeches have been used as a reference corpus with the 'compare corpora' tool. The comparability score calculated by Sketch Engine has reached 3.27 points for C corpus and 4.40 for $\mathrm{P}$ corpus, the latter being clearly more different regarding the lexis used than the Spanish president corpus. In addition, $\mathrm{P}$ corpus is more different from the Spanish president corpus than from $\mathrm{C}$ corpus (4.40 and 4.16 respectively).

Table 7 below shows the comparability scores of $\mathrm{C}$ corpus and $\mathrm{P}$ corpus by each president. 


\begin{tabular}{|l|c|l|c|}
\hline & Ciudadanos & & Podemos \\
\hline Calvo-Sotelo & 4.73 & Calvo-Sotelo & 5.74 \\
\hline Rajoy & 4.24 & Rajoy & 5.16 \\
\hline Podemos & 4.16 & Suárez & 5.01 \\
\hline Suárez & 3.92 & González & 4.93 \\
\hline Zapatero & 3.89 & Aznar & 4.90 \\
\hline Aznar & 3.80 & Zapatero & 4.90 \\
\hline González & 3.71 & Ciudadanos & 4.16 \\
\hline
\end{tabular}

Table 7: Comparability scores for $\mathrm{C}$ corpus, $\mathrm{P}$ corpus and the speeches by each Spanish president.

Both $\mathrm{C}$ corpus and $\mathrm{P}$ corpus are most different from Leopoldo Calvo-Sotelo's inaugural address (1981), which is also one of the most distant in time (4.73 and 5.74 respectively).

C corpus is most similar to Felipe González's speeches (3.71), followed by María José Aznar (3.8) and José Luis Rodríguez Zapatero (3.89). The following president regarding the comparability score is Adolfo Suárez, which is a surprising finding since Ciudadanos have often made references to the Spanish transition period and have claimed that they would replace the disappeared UCD, Suárez's party, by re-establishing the centre of the Spanish political spectrum.

The comparability scores for $\mathrm{P}$ corpus are on the whole higher than for $\mathrm{C}$ corpus, ranging from 4.16 (C corpus) to 5.74 (Calvo-Sotelo). $\mathrm{P}$ corpus is most similar to $\mathrm{C}$ corpus, when compared with the Spanish presidents' inaugural speeches. There is a nearly one point of difference with the presidents following C corpus in the comparability scores: Aznar and Zapatero (4.9) and González (4.93). Mariano Rajoy's speech scored a high 5.16 as compared to P corpus, and a lower 4.24 in comparison with $\mathrm{C}$ corpus.

In general terms, $\mathrm{C}$ corpus is distinct from the Spanish presidents' inaugural speeches to a lesser extent than $\mathrm{P}$ corpus, and in this sense the latter can indeed be considered as a sample of new political discourse. It seems that the manifesto of Podemos breaks away from the past political discourse of the governing parties, being the most similar to Ciudadanos' political manifesto. References to specific problems and to the problems that bother people, as well as the promises providing concrete solutions can be considered as instances of new rhetoric which has gained so many followers.

\section{Conclusions}

The present study has focused on the lexical choices made in the political manifestos of two new political parties participating in the 2015 Spanish general election: Ciudadanos and Podemos. Using the 'compare corpora' tool of Sketch Engine, and considering the use of keywords and their collocates, notable lexical differences between the manifestos of these parties have been identified, despite the fact that they both share similar broad programmatic goals. In this sense, the manifesto of Podemos can be described as placing emphasis on people's specific problems, on solutions to those problems, and on presenting future actions as completed. Quite to the contrary, the manifesto of Ciudadanos seems to focus more on the correct functioning of a democratic state, on the role of Spain as a member of a larger political structure, on its culture and languages as shared values, and on the need for future actions implying changes and improvements.

The analysis of keywords points to distinct ideological stances, but also to different communicative strategies, the manifesto of Podemos being more people-centered and that of Ciudadanos being closer to more conventional political discourse. Obviously, the examination of 
keywords only focuses on differences in lexical choices. However, it provides a useful short-cut to those differences, which should further be complemented by qualitative approaches ensuring a more detailed description of communicative intentions and strategies.

\section{References}

Charteris-Black, J. (2004). Why "an angel rides in the whirlwind and directs the storm": A corpusbased comparative study of metaphor in British and American political discourse. Language and Communication, 49, 133-150.

Cheng, W. (2004). // $\rightarrow$ FRIENDS // $\boldsymbol{y}$ 齐 LAdies and GENtlemen //: Some preliminary findings from a corpus of spoken public discourse in Hong Kong. In U. Connor \& T. A. Upton (Eds.), Applied Corpus Linguistics: A multidimensional perspective (pp. 35-50). Amsterdam: Rodopi.

Cheng, W. (2013). Corpus-based linguistic approaches to Critical Discourse Analysis. In C. A. Chappelle (Ed.), The Encyclopedia of Applied Linguistics (pp. 1-8). London: Blackwell Publishing Ltd.

Fairclough, N. (2000). New Labour, new language? London: Routledge.

Fairclough, N. (2001). Language and Power ( $2^{\text {nd }}$ ed.). London: Longman.

Hoey, M. (2005). Lexical Priming. London: Routledge.

Miliza, D. (2006). Classifying phraseology in a spoken corpus of political discourse. ESP Across Cultures, 3, 41-65.

Salama, A. H. Y. (2011). Ideological collocation and the recontextualization of Wahhabi-Saudi islam post-9/11: A synergy of corpus linguistics and critical discourse analysis. Discourse \& Society 22(3), 315-342.

Sinclair, J. M. (1996). The search for units of meaning. Textus, 9(1), 75-106.

Sinclair, J. M. (1991). Corpus, concordance, collocation. Oxford: Oxford University Press.

Stubbs, M. (1997). Whorf's children: Critical comments on critical discourse analysis (CDA). In A. Ryan \& A. Wray (Eds.), Evolving Models of Language (pp. 110-116). Clevendon: BAAL in association with Multilingual Matters.

van Dijk, T. (1997). What is political discourse analysis? In J. Blommaert \& C. Bulcaen (Eds.), Political Linguistics (pp. 11-52). Amsterdam: John Benjamins.

Wodak, R. (2001). The discourse historical approach. In R. Wodak \& M. Mayer (Eds.), Methods of Critical Discourse Analysis (pp. 63-94). London: Sage. 